\title{
MENINGKATKAN AKTIVITAS BELAJAR SISWA DENGAN MODEL PEMBELAJARAN INKUIRI PADA MATA PELAJARAN ILMU PENGETAHUAN ALAM (IPA) DI KELAS V-ASD NEGERI 101775 SAMPALI
}

\author{
Wesly Silalahi, Syahira Dana Nasution \\ Surel:weslysilalahi@yahoo.com
}

\begin{abstract}
The purpose of this study was to find out how to improve student learning activities with Inquiry learning models in Natural Sciences (IPA) subjects. The method of this research is Classroom Action Research (CAR) with the subject of all students of class V-A SD Negeri 101775 Sampali which amounted to 31 students. The data collection technique for this study is to use observations on student learning activities as well as distributing learning activity questionnaires to students. By observing student learning activities, in Cycle I of 1st Meeting there were 9 active students with a percentage of $32.26 \%$. In Meeting Cycle I there were 16 active students with a percentage of $51.61 \%$. Furthermore, there was a good increase in Cycle II of Meeting 1. There were 25 active students with a percentage of $80.65 \%$ and in Cycle II the 2nd Meeting became $90.32 \%$ with many active students, 28 students. While the results of questionnaires showed that in Cycle I, there were 16 students classified as active with a percentage of $51.61 \%$, then in Cycle II it rose to 28 students with a percentage of $90.32 \%$. From these results it can be said that this study was successful.
\end{abstract}

Keywords: Learning activities, Science subjects, Inquiry learning models

\begin{abstract}
ABSTRAK
Tujuan penelitian ini adalah untuk mengetahui bagaimana peningkatanaktivitas belajar siswa dengan model pembelajaran Inkuiri pada mata pelajaran Ilmu Pengetahuan Alam (IPA). Metode penelitian ini adalah Penelitian Tindakan Kelas (PTK) dengan subjek seluruh siswa kelas V-A SD Negeri 101775 Sampali yang berjumlah 31 siswa.Teknik pengumpulan data untuk penelitian ini adalah dengan menggunakan pengamatan terhadap aktivitas belajar siswa sekaligus penyebaran angket aktivitas belajar kepada siswa. Dengan melakukan pengamatan aktivitas belajar siswa, pada Siklus I Pertemuan 1 terdapat 9 orang siswa yang aktif dengan persentase 32,26\%. Pada Siklus I Pertemuan 2 terdapat 16 orang siswa yang aktif dengan persentase $51,61 \%$. Selanjutnya, terjadi peningkatan yang baik pada Siklus II Pertemuan 1 terdapat 25 orang siswa yang aktif dengan persentase 80,65\% dan pada Siklus II Pertemuan 2 menjadi 90,32\% dengan banyak siswa yang aktif yaitu 28 orang siswa. Sedangkan hasil penyebaran angket menunjukkan pada Siklus I, terdapat 16 orang siswa yang tergolong aktif dengan persentase $51,61 \%$, lalu pada Siklus II naik menjadi 28 orang siswa dengan persentase $90,32 \%$. Dari hasil tersebut maka dapat dikatakan bahwa penelitian ini berhasil.
\end{abstract}

Kata Kunci: Aktivitas belajar, Mata pelajaran IPA, Model pembelajaran Inkuiri. 

Wesly Silalahi: Meningkatkan Aktivitas Belajar Siswa ...

\section{PENDAHULUAN}

Pembelajaran

Ilmu

Pengetahuan Alam (IPA) adalah pembelajaran tentang pengetahuan yang rasional dan objektif tentang alam semesta beserta isinya IPA membahas tentang segala sesuatu yang terjadi di alam ini yang disusun secara sistematis berdasarkan hasil percobaan dan pengamatan yang dilakukan manusia. IPA tidak hanya merupakan kumpulan pengetahuan tentang benda atau makhluk hidup, tapi memerlukan cara berpikir dan cara memecahkan masalah. Singkatnya, IPA adalah sebuah pengetahuan tentang alam beserta isinya yang didapat dari kerja ilmiah yang dilakukan oleh manusia.

Pembelajaran IPA di

Sekolah Dasar (SD) hendaknya membuka kesempatan untuk memupuk rasa ingin tahu siswa secara ilmiah. Hal ini akan membantu siswa dalam berpikir kritis dan mencari jawaban berdasarkan bukti yang ada. Piaget mengatakan bahwa siswa SD (usia 711 tahun) mulai menyesuaikan diri dengan realitas konkrit dan sudah mulai berkembang rasa ingin tahunya. Cara berpikir siswa masih bersifat konkrit yang menyebabkan mereka belum mampu menangkap sesuatu yang abstrak.Maka dari itu, mereka harus belajar melalui pengalaman langsung (learning by doing).

IPA tidak menyediakan semua jawaban untuk semua masalah yang kita ajukan.Dalam IPA siswa dan kita harus bersifat skeptis sehingga kita selalu siap memodifikasi model-model yang kita punyai tentang alam ini sejalan dengan penemuan-penemuan baru yang kita dapatkan. Artinya siswa juga tidak hanya diajak untuk melakukan percobaan untuk menguji kebenaran suatu konsep IPA yang sudah diketahui sebelumnya, namun juga siswa harus diajak untuk menemukan sesuatu yang baru dari hal sudah diketahui sebelumnya. Intinya, dari jabaran di atas, pembelajaran IPA hendaknya melibatkan siswa aktif secara langsung dalam pembelajaran.

Namun, pada kenyataannya pembelajaran IPA di sekolah, terutama di SD tidak sesuai dengan harapan. Berdasarkan hasil pengamatan peneliti di sekolah ia melaksanakan program PPLT yaitu di kelas V-A T.A 2017/2018 SD Negeri 101775 Sampali khususnya, guru kurang mampu dalam menerapkan gaya belajar IPA yang mengajak siswa aktif dalam pembelajaran. Pembelajaran IPA hanya berpusat pada guru, sehingga tidak melibatkan siswa secara langsung dalam pembelajaran.

Dari uraian masalah di atas, maka peneliti beranggapan bahwa model pembelajaran Inkuiri mampu menyelesaikan masalah pembelajaran IPA di kelas V-A SD Negeri 101775 Sampali T.A 2017/2018. Hal ini dikarenakan model pembelajaran Inkuiri merupakan salah satu model pembelajaran yang mendorong siswa untuk belajar aktif, berpikir kritis, 
analitis dan ilmiah untuk menemukan konsep-konsep materi berdasarkan masalah yang diajukan.

Pembelajaran ini bisa menekankan siswa untuk aktivitas mencari dan menemukan. Siswa berperan sebagai subjek belajar, siswa tidak hanya menerima materi dari guru secara verbal. Tetapi mereka juga diharpkan untuk menemukan sendiri inti dari pelajaran itu sendiri.

Model pembelajaran Inkuiri mencakup kegiatan orientasi, merumuskan masalah sesuai dengan materi pembelajaran, mengajukan hipotesis, mengumpulkan data melalui pengamatan atau membaca sumber belajar, menguji hipotesis berdasarkan data yang telah dikumpulkan, dan merumuskan kesimpulan.

Dari tahap-tahap model pembelajaran Inkuiri tersebut, dapat dilihat bahwa seluruh tahap pembelajarana melibatkan siswa untuk berkativitas untuk menemukan konsep IPA melalui suatu permasalahan. Dalam pembelajaran model Inkuiri, guru hanya sebagai fasilitator dan monitor jalannya pembelajaran. Siswa belajar sendiri dan merasakan pengalaman pembelajaran secara langsung, dengan begitu pembelajaran akan bermakna dan pembelajaran pun akan terus diingat oleh siswa karena dia turut aktif dalam pembelajaran, sehingga pada akhirnya hasil belajar yang baik pun dapat dicapai.

Pembelajaran IPA tidak seperti yang diharapkan. Aktivitas belajar IPA dikatakan rendah. Hal ini dikarenakan guru tidak menerapkan gaya belajar yang mampu mengajak siswa aktif dalam pembelajaran, guru hanya mentransfer ilmunya dengan metode ceramah. Selain itu, hasil belajar yang baik menjadi prioritas utama guru dalam mengajar, tanpa mempedulikan peningkatan aktivitas belajar siswa.

Maka dari itu dibutuhan suatu pembaharuan model pembelajaran yang mampu mengaktifkan siswa. Dimana model pembelajaran tersebut memusatkan pembelajaran terhadap siswa dan aktivitas belajar siswa. Salah satu model pembelajaran yang dapat digunakan adalah model pembelajaran Inkuiri.Pembelajaran ini menekankan siswa untuk aktivitas mencari dan menemukan. Siswa berperan sebagai subjek belajar, siswa tidak hanya menerima materi dari guru secara verbal. Tetapi mereka juga diharapkan untuk menemukan sendiri inti/konsep IPA dari pelajaran itu sendiri.

\section{METODE PENELITIAN}

Jenis penelitian yang dilakukan dalam penelitian ini adalah Penelitian Tindakan Kelas (PTK) yang bertujuan untuk memperbaiki proses pembelajaran dan meningkatkan aktivitas belajar siswa dalam mata pelajaran IPA dengan menggunakan model pembelajaran Inkuiri di kelas V-A SD Negeri 101775 Sampali.

Penelitian dilakukan di kelas V-A SD Negeri 101775 Sampali T.A 2017/2018 pada semester 
genap.Penelitian ini dilaksanakan pada bulan Januari sampai bulan Maret tahun 2018.

Subjek penelitian ini adalah, siswa kelas V-A SD Negeri 101775 Sampali yang berjumlah 31 siswa. Sedangkan yang menjadi objek penelitian ini adalah model pembelajaran Inkuiri yang diharapkan dapat meningkatkan aktivitas belajar siswa pada mata pelajaran IPA pokok bahasan gaya dan perubahannya.
Penelitian ini menggunakan desain model Kemmis dan MC. Taggart (dalam Arikunto, 2013:137). Menurut Kemmis dan MC. Taggart, PTK dibagi dalam empat tahap kegiatan pada satu putaran (siklus) yaitu: perencanaan - pelaksanaaan pengamatan - refleksi. Pelaksanaan dan pengamatan atau observasi dilakukan sejalan. Guru melaksanakan tindakan sekaligus mengobservasi aktivitas belajar siswa.

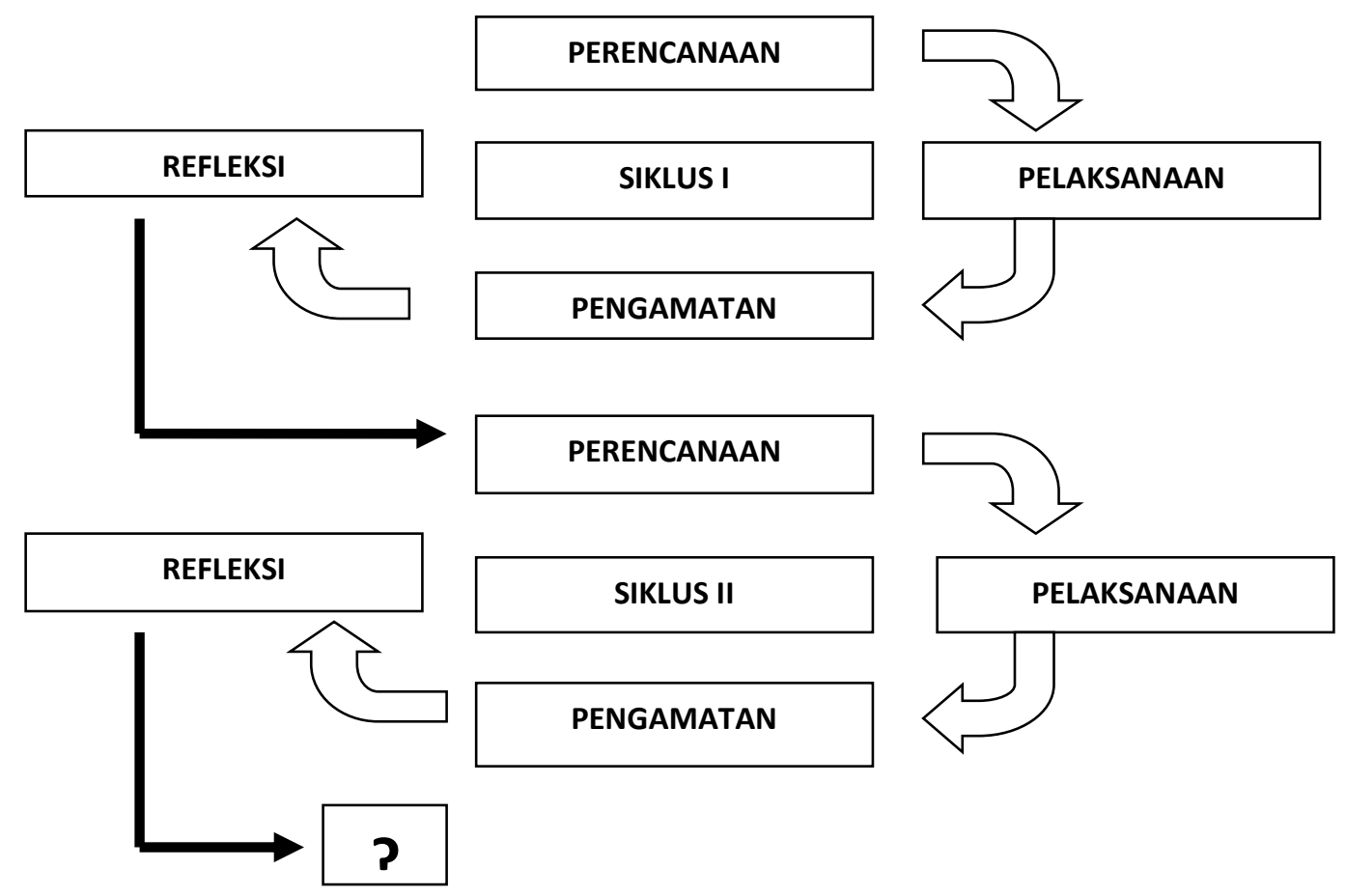

Gambar 1. Desain Pelaksanaan Penelitian Tindakan Kelas Menurut Kemmis dan Mc Taggart (dalam Arikunto, 2013:137)

HASIL PENELITIAN DAN PEMBAHASAN

Penelitian ini dilakukan di bulan Januari hingga Maret tahun 2018 di SD Negeri 101775 Sampali. Pengambilan data dimulai dari bulan
Januari hingga Februari tahun 2019. Pengambilan data dilakukan sebanyak 4 kali pertemuan dan dibagi menjadi dua Siklus, Siklus I dan Siklus II. Siklus I terdapat dua kali pertemuan yaitu pertemuan 1 
dan 2, begitu juga Siklus II yaitu pertemuan 3 dan 4 . Sebelum dilakukan Siklus I atau tepatnya sebelum pertemuan pertama, dilakukan sebelum dilaksanakannya tindakan (pretes) untuk melihat aktivitas awal siswa.

Setelah

dilakukan

pembelajaran dengan model pembelajaran Inkuiri di kelas V-A SD Negeri 101775 Sampali T.A 2017/2018, diperoleh perubahan yang signifikan dari aktivitas belajar siswa. Selalu terjadi peningkatan aktivitas belajar di tiap-tiap pertemuan pada Pretes, Siklus I maupun Siklus II.

Pada Pretes hanya ada 5 orang siswa yang dapat dikategorikan aktif dengan persentase $16,13 \%$. Kelima siswa yang dikategorikan aktif tersebut, semuanya memperoleh nilai pada rentang 65-74.Hal ini masih sangat jauh dari angka yang diharapkan.

Pada Siklus I Pertemuan 1, ada 9 orang yang dikategorikan aktif dengan persentase $32,26 \%$. 1 orang siswa mendapatkan nilai pada rentang 85-100, 4 orang siswa mendapatkan nilai pada rentang 7584,5 orang siswa lainnya mendapat nilai pada tentang 65-74. Sementara itu, pada Siklus I Pertemuan 2 ada 16 orang siswa yang dikategorikan aktif dengan persentase 51,62\%. 5 orang siswa mendapatkan nilai pada rentang 85-100.2 orang siswa mendapatkan nilai pada rentang 7584 dan 9 orang siswa lainnya mendapat nilai pada tentang 65-74. Maka, jika dihitung dalam persen, persentase keaktifan siswa sebesar $51,62 \%$, tindakan belum dikatakan berhasil. Jika dihitung dengan taraf keberhasilan, angka itu hanya memenuhi kriteria Kurang.Maka dari itu, peneliti melanjutkan ke tahap berikutnya yaitu Siklus II. Pola pada Siklus II sama halnya dengan Siklus I, hanya saja terdapat beberapa perbaikan pembelajaran di Siklus I yang harus dibenahi di Siklus II.

Pada Siklus II Pertemuan 1 terdapat 25 orang siswa yang dikategorikan aktif dengan persentase $80,65 \%, 7$ orang siswa mendapatkan nilai pada rentang 85100, 7 orang siswa mendapatkan nilai pada rentang 75-84 dan 11 orang siswa lainnya mendapat nilai pada tentang 65-74 yang. Persentase ini telah menunjukkan keberhasilan dalam pelaksaan tindakan kelas ini.Dimana persentase ini melebihi angka $75 \%$. Meskipun begitu, peneliti hendak menginginkan hasil yang lebih baik lagi pastinya. Selanjutnya di Siklus II Pertemuan 2 terdapat 28 siswa yang dikategorikan aktif dengan persentase 90,32\%. 12 orang siswa mendapatkan nilai pada rentang 85-100, 15 orang siswa mendapatkan nilai pada rentang 7584 dan 1 orang siswa lainnya mendapat nilai pada tentang 65-74.

Di akhir pertemuan, hanya ada 3 orang siswa yang tidak dapat dikategorikan aktif. Meskipun begitu, keaktifan siswa tersebut terus meningkat dari siklus ke siklus, hanya saja belum memenuhi kriteria untuk dikatakan sebagai siswa yang aktif. Jadi dengan persentase akhir 
Wesly Silalahi: Meningkatkan Aktivitas Belajar Siswa ...

90,32\% dan diukur dengan taraf keberhasilan, penelitian tindakan kelas ini sudah berhasil dengankategoritaraf keberhasilan Baik Sekali.
Penyebaran angket di setiap akhir siklus juga menunjukkan peningkatan aktivitas belajar siswa. Hal ini dapat dilihat dari tabel berikut:

Tabel 1. Rekapitulasi Peningkatan Aktivitas Belajar Siswa pada Siklus I dan II Berdasarkan Angket

\begin{tabular}{|c|c|c|c|c|}
\hline \multirow{2}{*}{ No } & \multirow{2}{*}{$\begin{array}{l}\text { Kode } \\
\text { Siswa }\end{array}$} & \multicolumn{2}{|c|}{$\begin{array}{c}\text { Nilai Penyebaran } \\
\text { Angket }\end{array}$} & \multirow[t]{2}{*}{ Keterangan } \\
\hline & & Siklus I & Siklus II & \\
\hline 1 & 001 & 59.38 & 68.13 & Meningkat dan Aktif \\
\hline 2 & 002 & 56.25 & 71.88 & Meningkat dan Aktif \\
\hline 3 & 003 & 65.00 & 75.63 & Meningkat dan Aktif \\
\hline 4 & 004 & 29.38 & 34.38 & Meningkat Tetapi Tidak Aktif \\
\hline 5 & 005 & 87.50 & 93.13 & Meningkat dan Aktif \\
\hline 6 & 006 & 60.00 & 78.13 & Meningkat dan Aktif \\
\hline 7 & 007 & 70.00 & 84.38 & Meningkat dan Aktif \\
\hline 8 & 008 & 65.00 & 81.25 & Meningkat dan Aktif \\
\hline 9 & 009 & 65.63 & 82.50 & Meningkat dan Aktif \\
\hline 10 & 010 & 50.00 & 80.00 & Meningkat dan Aktif \\
\hline 11 & 011 & 68.13 & 80.63 & Meningkat dan Aktif \\
\hline 12 & 012 & 51.25 & 82.50 & Meningkat dan Aktif \\
\hline 13 & 013 & 65.00 & 85.00 & Meningkat dan Aktif \\
\hline 14 & 014 & 46.25 & 71.88 & Meningkat dan Aktif \\
\hline 15 & 015 & 35.63 & 46.88 & Meningkat Tetapi Tidak Aktif \\
\hline 16 & 016 & 49.38 & 73.75 & Meningkat dan Aktif \\
\hline 17 & 017 & 92.50 & 98.13 & Meningkat dan Aktif \\
\hline 18 & 018 & 84.38 & 91.88 & Meningkat dan Aktif \\
\hline 19 & 019 & 81.88 & 91.25 & Meningkat dan Aktif \\
\hline 20 & 020 & 35.00 & 43.75 & Meningkat Tetapi Tidak Aktif \\
\hline 21 & 021 & 58.13 & 76.25 & Meningkat dan Aktif \\
\hline 22 & 022 & 94.38 & 96.25 & Meningkat dan Aktif \\
\hline 23 & 023 & 70.00 & 80.63 & Meningkat dan Aktif \\
\hline 24 & 024 & 65.00 & 76.25 & Meningkat dan Aktif \\
\hline 25 & 025 & 53.75 & 75.63 & Meningkat dan Aktif \\
\hline 26 & 026 & 58.13 & 73.13 & Meningkat dan Aktif \\
\hline 27 & 027 & 70.00 & 81.88 & Meningkat dan Aktif \\
\hline 28 & 028 & 43.13 & 74.38 & Meningkat dan Aktif \\
\hline 29 & 029 & 61.88 & 73.75 & Meningkat dan Aktif \\
\hline
\end{tabular}




\begin{tabular}{c|c|c|c|c}
\hline 30 & 030 & 91.25 & 93.13 & Meningkat dan Aktif \\
\hline 31 & 031 & 84.38 & 93.75 & Meningkat dan Aktif \\
\hline \multicolumn{3}{c}{ Jumlah Siswa yang Meningkat dan Aktif } & 28 \\
\hline & Jumlah Siswa yang Meningkat Tetapi Tidak \\
Aktif
\end{tabular}

Pada penyebaran angket di Siklus I terdapat 16 orang siswa dikategorikan aktif. Dapat dilihat bahwa terdapat 4 siswa mendapat kriteria Sangat Aktif dengan persentase $12,90 \%$, sebanyak 3 siswa mendapat kriteria Aktif dengan persentase $9,68 \%$, sebanyak 9 siswa mendapat kriteria Cukup Aktif dengan persentase $29,03 \%$, sebanyak 6 siswa mendapat kriteria Kurang Aktif dengan persentase 19,35\% dan sisanya 9 siswa mendapat kriteria Sangat Kurang Aktif dengan persentase $29,03 \%$.
Sementara pada penyebaran angket di Siklus II terdapat 28 orang siswa dikategorikan aktif. 8 siswa mendapat kriteria Sangat Aktif dengan persentase $25,81 \%$, sebanyak 13 siswa mendapat kriteria Aktif dengan persentase $41,94 \%$, sebanyak 7 siswa mendapat kriteria Cukup Aktif dengan persentase 22,58\%, tidak ada siswa yang mendapat kriteria Kurang Aktif, sementara sisanya 3 siswa mendapat kriteria Sangat Kurang Aktif dengan persentase $9,68 \%$.

\section{Grafik 1. Diagram Persentase Peningkatan Aktivitas Belajar Siswa pada Pretes, Siklus I dan Siklus II}

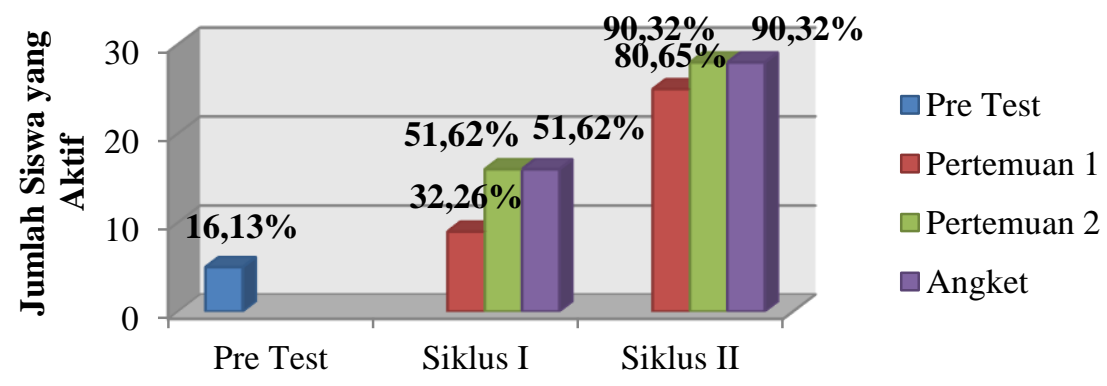

Dari pembahasan diatas dapat disimpulkan bahwa penerapan model pembelajaran Inkuiri pada mata pelajaran IPA materi Gaya dan Perubahannya di kelas V-A SD Negeri 101775 Sampali T.A 2017/2018 mampu meningkatkan aktivitas belajar siswa.

\section{SIMPULAN}

Berdasarkan hasil penelitian dan pembahasan mengenai penerapan model pembelajaran Inkuiri pada mata pelajaran IPA materi Gaya dan Perubahannya di kelas V-A SD Negeri 101775 
Sampali T.A 2017/2018, peneliti dapat menyimpulkan:

a. Aktivitas belajar siswa berdasarkan hasil pengamatan meningkat dari siklus ke siklus. Pada Siklus I Pertemuan 1 terdapat 9 orang siswa yang aktif dengan persentase $32,26 \%$. Pada Siklus I Pertemuan 2 terdapat 16 orang siswa yang aktif dengan persentase $51,62 \%$. Selanjutnya, terjadi peningkatan yang baik pada Siklus II Pertemuan 1 terdapat 25 orang siswa yang aktif dengan persentase $80,65 \%$ dan angka ini terus naik pada Siklus II Pertemuan 2 menjadi 90,32\% dengan banyak siswa yang aktif yaitu 28 orang siswa.

b. Aktivitas belajar siswa berdasarkan angket juga mendukung aktivitas belajar siswa berdasarkan hasil pengamatan. Pada Siklus I, terdapat 16 orang siswa yang tergolong aktif dengan persentase $51,62 \%$, lalu pada Siklus II naik menjadi 28 orang siswa dengan persentase $90,32 \%$.

c. Dari hasil penelitian dan pembahasan terbukti penerapan model pembelajaran Inkuiri pada mata pelajaran IPA materi Gaya dan Perubahannya di kelas V-A SD Negeri 101775 Sampali T.A 2017/2018 mampu meningkatkan aktivitas belajar siswa dengan memenuhi kriteria "baik sekali".

\section{DAFTAR RUJUKAN}

Al-Tabany, Trianto. 2014. Mendesai Model Pembelajaran Inovatif, Progresif dan Kontekstual. Bandung: Kencana

Arikunto, Suharsimi. 2013. Prosedur Penelitian Suatu Pendekatan Praktik. Jakarta: Rineka Cipta.

Dewi, Rosmala. 2015. Penelitian Tindakan Kelas. Medan: Unimed Press.

Dimyati, dkk. 2013. Belajar dan Pembelajaran. Jakarta: Rineka Cipta.

Djamarah,B,S. 2016. Psikologi Belajar. Jakarta: Rineka Cipta.

Fathurrohman, Muhammad. 2015. Model-model Pembelajaran Inovatif. Jogjakarta: Ar-Ruz Media.

Istarani dan Bancin. 2017. Aktivitas Belajar. Medan: Iscom.

Kurniasih, Imas \& Berlin, Sani. 2014. Teknik \& Cara Mudah Membuat Penelitian Tindakan Kelas. Jakarta: Kata Pena.

Lubis, Iqlima Zora. 2016. Skripsi: Upaya Meningkatkan Aktivitas Belajar Siswa Melalui Model Pembelajaran Tipe STAD (Student Teams Achievement Division) Pada Pembelajaran Bahasa Indonesia Kelas $V$ SDN 053964 Hinai Kanan T.A 2015/2016. Medan.

Samatowa, Usman. 2011. Pembelajaran IPA di Sekolah Dasar. Jakarta: Indeks.

Sanjaya, Wina. 2014. Strategi Pembelajaran. Bandung: Kencana. 
Sardiman. 2013. Interaksi dan Motivasi Belajar Mengajar. Jakarta: Rajagrafindo Persada.

Shoimin, Aris. 2014. 68 Model Pembelajaran Inovatif dalam Kurkulum 2013. Yogyakarta: Ar-Ruzz Media.

Slameto. 2010. Belajar dan Faktor yang Mempengaruhi. Jakarta: Rineka Cipta.

Sugiyono. 2013. Metode Penelitian Kuantitatif dan Kualitatif dan $R \& D$. Bandung. Alfabeta.

Trianto. 2014. Model Pembelajaran Terpadu. Jakarta: Bumi Aksara.

Wonorahardjo, Surjani. 2010. Dasardasar Sains. Jakarta: Indeks. 